\title{
Analisis kecepatan dan kelincahan dalam menggiring bola pada tim futsal
}

\author{
Adi Purnomo a ${ }^{*}$, Fajar Awang Irawan ${ }^{b}$ \\ Jurusan Ilmu Keolahragaan, Fakultas Ilmu Keolahragaan, Universitas Negeri Semarang, Indonesia \\ a adipurnomo2103@yahoo.com, b fajarawang@mail.unnes.ac.id \\ * Corresponding Author
}

Received: 12 January 2021; Revised: 15 January 2021; Accepted: 20 January 2021

Abstrak. Tujuan dari penelitian ini adalah untuk mengetahui hubungan antara kecepatan dan kelincahan terhadap keterampilaan menggiring bola pada tim futsal Jatidiri Muda Semarang. Metode penelitian yang digunakan adalah metode survei dengan teknik tes dan teknik korelasi. Instrumen yang digunakan dalam penelitian ini adalah tes sprint 30 meter untuk kecepatan, tes Illinois Agility Run untuk kelincahan, dan tes menggiring bola untuk keterampilan menggiring bola. Teknik analisis data yang digunakan adalah teknik analisis korelasi product moment dengan taraf signifikansi $(\alpha)=5 \%$. Hasil penelitian dari uji korelasi antara X1 dan Y didapat nilai Sig. sebesar 0,042 $(<0,05)$ dan hasil uji korelasi antara X2 dan Y didapat nilai Sig. sebesar 0,03 $(<0,05)$. Sedangkan hasil uji korelasi berganda nilai Sig. F change sebesar 0,001 $(<0,05)$. Dapat disimpulkan bahwa kecepatan dan kelincahan memiliki hubungan yang signifikan terhadap keterampilan menggiring bola tim futsal Jatidiri Muda Semarang. Diharapkan dengan adanya penelitian ini pelatih dapat memperhatikan dan meningkatkan latihan kecepatan, kelinahan, dan keterampilan dalam menggiring bola atlet Futsal Jatidiri Muda Semarang.

Kata Kunci: Futsal, Kecepatan, Kelincahan, Menggiring Bola

\section{Analysis of speed and agility in dribbling the futsal team}

Abstract. The purpose of this study was to determine the relationship between speed and agility on dribbling skills in the Jatidiri Muda Semarang futsal team.The research method used is a survey method with test techniques and correlation techniques. The instruments used in this study were the 30 meter sprint test for speed, the Illinois Agility Run test for agility, and the dribbling test for dribbling skills. The data analysis technique used is the product moment correlation analysis technique with a significance level $(\alpha)=5 \%$. The research results from the correlation test between X1 and Y obtained the Sig. of 0.042 $(<0.05)$ and the results of the correlation test between X2 and Y obtained the Sig. of $0.03(<0.05)$. While the result of multiple correlation test is Sig. F change is $0.001(<0.05)$. It can be concluded that speed and agility have a significant relationship to the dribbling skills of the Jatidiri Muda Semarang futsal team. Keywords: Futsal, Speed, Agility, Dribbling

How to Cite: Purnomo, A., \& Irawan, F. (2021). Analisis kecepatan dan kelincahan dalam menggiring bola pada tim futsal. Sepakbola, 1(1), 1-7. doi:http://dx.doi.org/10.33292/sepakbola.v1i1.90

\section{PENDAHULUAN}

Futsal merupakan salah satu cabang olahraga yang sangat digemari oleh sebagian besar manusia bahkan mendapat simpati dari masyarakat Indonesia. Olahraga futsal dimainkan oleh 5 anggota dari masing-masing tim dan diizinkan memiliki pemain cadangan. Futsal menggunakan bola yang lebih kecil dan lebih berat dibandingkan dengan bola yang digunakan pada permainan sepakbola. Gawang futsal lebih kecil, karena dengan ukuran lapangan yang lebih kecil, dan jumlah pemain yang lebih sedikit dari sepakbola. Menurut Lhaksana (2011) teknik dasar yang harus dikuasai dalam bermain futsal adalah mengumpan (Passing), menahan bola (Control), mengumpan lambung (Chipping), menggiring bola (Dribbling) dan menembak bola (Shooting). Dari teknik dasar di atas salah satu teknik yang sangat penting untuk dikuasai oleh pemain futsal yaitu 
Sepakbola, 1 (1), 2021, 2

Adi Purnomo, Fajar Awang Irawan

kemampuan menggiring bola (Dribbling). Menurut Sunarno (2008) agar bisa menjadi pemain futsal yang baik seorang pemain harus selalu fokus dan mempunyai suatu konsentrasi yang tinggi.

Menurut Tenang (2007) menggiring artinya melakukan beberapa sentuhan pada bola. Biasanya kaki yang dibenturkan pada bagian pinggir bola. Menurut Lhaksana (2011) Teknik dribbling merupakan keterampilan penting dan mutlak harus dikuasai oleh setiap pemain futsal. Ketika seorang pemain memiliki kemampuan menggiring bola yang baik maka pemain akan sangat mudah untuk melewati lawan, mengatur tempo permainan, dan memudahkan untuk masuk ke pertahanan lawan sehingga kesempatan untuk memenangkan pertandingan sangat terbuka. Dalam olahraga futsal unsur kondisi fisik sangat dibutuhkan. Beberapa komponen kesegaran jasmani yang berkaitan dengan kondisi fisik, yaitu kekuatan, kelentukan, komposisi tubuh, daya tahan (kardiorespirasi dan otot), kecepatan, kelincahan, keseimbangan, koordinasi dan kecepatan reaksi (Nurhasan, 2011). Kondisi fisik sangat berperan dalam cabang olaharaga futsal. Kecepatan dan kelincahan dibutuhkan oleh pemain futsal dalam menghadapi situasi tertentu dan kondisi pertandingan yang menuntut unsur kecepatan dan kelincahan dalam bergerak untuk menguasai bola.

Kecepatan berhubungan dengan bagaimana seseorang membawa bola ke dengan cepat. Kelincahan berhubungan dengan bagaimana seseorang dapat mengubah arah atau posisi dengan cepat dan tepat (Irawan \& Hariadi, 2019). Menurut Widiastuti (2019) Kelincahan adalah kemampuan mengubah arah atau posisi tubuh denga $n$ cepat yang dilakukan bersama-sama dengan gerak lainnya. Seorang pemain futsal yang memiliki kecepatan dan kelincahan yang baik pada saat menggiring bola akan mudah untuk menghindari lawan. Selaras dengan pernyataan Akhmad et al. (2018) bahwa "Apabila pemain sepakbola memiliki kecepatan, kelincahan secara bersamasama dalam kondisi yang baik akan mampu melakukan seluruh rangkaian dalam pelaksanaan gerakan menggiring bola pada permainan sepak bola".

Berdasarkan penjelasan tersebut bahwa kecepatan dan kelincahan sangat penting bagi pemain futsal dalam menguasai teknik menggiring bola. Hal ini sangat bertolak belakang dengan pemain futsal tim Jatidiri Muda Semarang. Hasil observasi menjelaskan bahwa pemain futsal tim Jatidiri Muda Semarang memiliki kondisi fisik yang kurang baik. Hasil wawancara dengan Agus Julianto selaku pelatih tim Jatidiri Muda, menyatakan bahwa tim Jatidiri Muda masih memiliki kekurangan dalam melakukan penguasaan teknik, terutama teknik dasar dribble. Hal ini dikarenakan fisik pemain Jatidiri Muda masih sangat lemah di kondisi fisik seperti kecepatan dan kelincahan, kurangnya tingkat pengetahuan pemain tentang faktor apa saja yang mendukung dalam teknik dribble.

Faktor permasalahan tersebut yang membuat penulis tertarik untuk meneliti tentang hubungan antara kecepatan dan kelincahan terhadap keterampilaan menggiring bola pada tim futsal Jatidiri Muda Semarang.

\section{METODE}

Penelitian ini menggunakan jenis penelitian korelasional, artinya yang hendak menyelidiki ada atau tidaknya hubungan antara variabel bebas dan variabel terikat. Yang menjadi variabel bebas dalam penelitian ini adalah kecepatan (X1) dan kelincahan (X2) sedangkan variabel terikatnya adalah keterampilan menggiring bola (Y). Metode penelitian yang digunakan adalah metode survei dengan teknik tes dan teknik korelasi. Sampel dalam penelitian ini adalah atlet putra futsal klub Jatidiri Muda Kota Semarang berusia 16-19 tahun dan populasi pada penelitian ini berjumlah 20 orang. Teknik pengambilan sampel dalam penelitian ini adalah teknik total sampling.

Instrumen yang digunakan dalam penelitian ini adalah tes sprint 30meter untuk kecepatan, tes Illinois Agility Run untuk kelincahan, dan tes menggiring bola untuk keterampilan menggiring bola. Teknik analisis data yang digunakan adalah teknik analisis korelasi product moment dengan taraf signifikansi $(\alpha)=5 \%$. 
Sepakbola, 1 (1), 2021, 3

Adi Purnomo, Fajar Awang Irawan

\section{HASIL DAN PEMBAHASAN}

Hasil penelitian ini didapatkan dari hasil analisis data yang telah dilakukan terhadap data dari hasil tes kecepatan, kelincahan dan keterampilan menggiring bola. Tabel 1 merupakan hasil analisis data penelitian.

Tabel 1. Hasil tes kecepatan atlet futsal Jatidiri Muda

\begin{tabular}{lcc}
\hline \multicolumn{1}{c}{ Kategori } & Frekuensi & $\%$ \\
\hline Baik Sekali & 1 & $5 \%$ \\
Baik & 7 & $35 \%$ \\
Sedang & 10 & $50 \%$ \\
Kurang & 2 & $10 \%$ \\
Kurang Sekali & 0 & $0 \%$ \\
\multicolumn{1}{c}{ Total } & 20 & $100 \%$ \\
\hline
\end{tabular}

Sumber: Penelitian 2020

Tabel 1 menunjukan bahwa tingkat kecepatan yang dimiliki oleh atlet futsal Jatidiri Muda Semarang terdapat pada kategori "sedang" yang mendominasi, yaitu sebanyak 10 atlet. Sedangkan pada kategori "baik sekali" kategori yang paling sedikit frekuensinya, yaitu hanya ada 1 atlet.

Tabel 2. Hasil tes kelincahan atlet Futsal Jatidiri Muda

\begin{tabular}{lcc}
\hline \multicolumn{1}{c}{ Kategori } & Frekuensi & $\%$ \\
\hline Baik Sekali & 0 & $0 \%$ \\
Baik & 2 & $10 \%$ \\
Sedang & 13 & $65 \%$ \\
Kurang & 4 & $20 \%$ \\
Kurang Sekali & 1 & $5 \%$ \\
\multicolumn{1}{r}{ Total } & 20 & $100 \%$ \\
\hline
\end{tabular}

Sumber: Penelitian 2020

Tabel 2 menjelaskan bahwa tingkat kelincahan atlet futsal Jatidiri Muda Semarang terdapat bahwa pada kategori "sedang" memiliki frekuensi terbanyak dibandingkan yang lainnya, yaitu sebanyak 13 atlet. Sedangkan pada kategori "kurang sekali" memiliki frekuensi terendah, yaitu hanya ada 1 atlet.

Tabel 3. Hasil tes keterampilan menggiring bola

\begin{tabular}{|c|c|c|}
\hline Kategori & Frekuensi & $\%$ \\
\hline Baik Sekali & 3 & $15 \%$ \\
\hline Baik & 3 & $15 \%$ \\
\hline Sedang & 9 & $45 \%$ \\
\hline Kurang & 4 & $20 \%$ \\
\hline Kurang Sekali & 1 & $5 \%$ \\
\hline Total & 20 & $100 \%$ \\
\hline
\end{tabular}

Sumber: Penelitian 2020

Tabel 3 menjelaskan bahwa keterampilan menggiring bola atlet futsal Jatidiri Muda Semarang terdapat bahwa pada kategori "sedang" memiliki frekuensi terbanyak, yaitu sebanyak 9 atltet. Sedangkan pada kategori yang paling rendah frekuensimya adalah kategori "kurang sekali" yaitu hanya ada 1 atlet.

\section{Hubungan Antara Kecepatan dengan Keterampilan Menggiring Bola}

Tabel 4. Hasil uji korelasi antara kecepatan dengan keterampilan menggiring bola tim futsal Jatidiri Muda Semarang

\begin{tabular}{cccc}
\hline Variabel & N & Sig. (2-tailed) & Keterangan \\
\hline Kecepatan (X1) - Keterampilan Menggiring Bola (Y) & 20 &, 042 & Signifikan \\
\hline Sumber: Penelitian 2020 & & &
\end{tabular}

Sumber: Penelitian 2020

Berdasarkan Tabel 4 menunjukan nilai Sig. (2-tailed) sebesar 0,042 $(<0,05)$ dapat disimpulkan bahwa terdapat hubungan yang signifikan antara kecepatan dengan keterampilan dalam menggiring bola pada tim futsal Jatidiri Muda Semarang. 
Sepakbola, 1 (1), 2021, 4

Adi Purnomo, Fajar Awang Irawan

\section{Hubungan Antara Kelincahan dengan Keterampilan Menggiring Bola}

Tabel 5. Hasil uji korelasi antara kelincahan dengan keterampilan menggiring bola tim futsal Jatidiri Muda Semarang

\begin{tabular}{cccc}
\hline Variabel & N & Sig. (2-tailed) & Keterangan \\
\hline Kelincahan (X2) - Keterampilan Menggiring Bola (Y) & 20 &, 030 & Signifikan \\
\hline
\end{tabular}

Sumber: Penelitian 2020

Berdasarkan Tabel 5 menunjukan nilai Sig. (2-tailed) sebesar 0,030 $(<0,05)$ dapat disimpulkan bahwa terdapat hubungan yang signifikan antara kelincahan dengan keterampilan dalam menggiring bola pada tim futsal Jatidiri Muda Semarang.

Hubungan Antara Kecepatan dan Kelincahan dengan Keterampilan Menggiring Bola

Tabel 6. Hasil uji korelasi berganda

\begin{tabular}{lcc}
\hline \multicolumn{1}{c}{ Variabel } & Sig. F Change & Keterangan \\
\hline Kecepatan dan Kelincahan - Keterampilan Menggiring Bola &, 001 & Signifikan \\
\hline Sumber: Penelitian 2020 & &
\end{tabular}

Berdasarkan Tabel 6 menunjukkan bahwa hasil uji korelasi berganda terdapat nilai Sig. F change sebesar 0,001 $(<0,05)$ dapat disimpulkan bahwa kecepatan dan kelincahan memiliki hubungan yang signifikan terhadap keterampilan menggiring bola tim futsal Jatidiri Muda Semarang.

Kecepatan merupakan kualitas kondisional yang memungkinkan seseorang untuk bereaksi secara cepat bila dirangsang dan untuk menampilkan atau melakukan gerakan secepat mungkin (Saputra \& Perdima, 2020). Berdasarkan hasil penelian yang dilakukan, bahwa tingkat kecepatan atlet futsal Jatidiri Muda Semarang tergolong "sedang". Hasil tersebut dapat dilihat seperti Gambar 1.

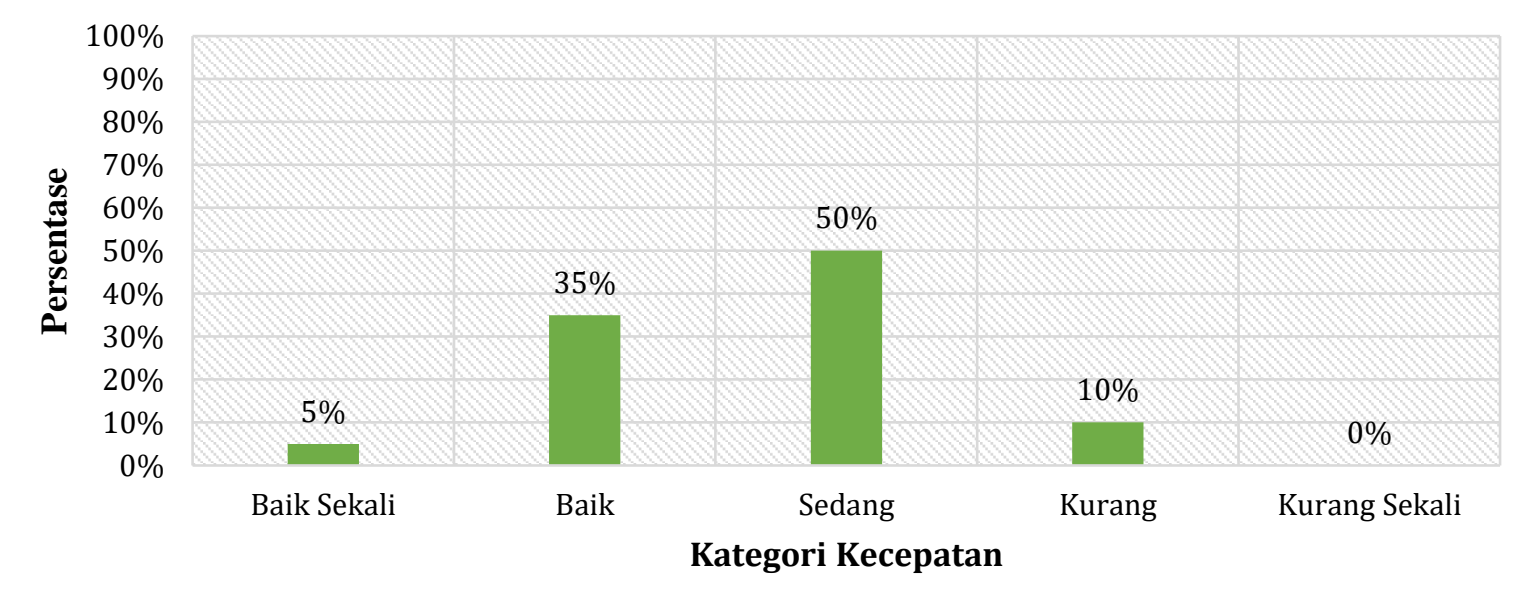

Gambar 1. Grafik kategori tingkat kecepatan atlet futsal Jatidiri Muda Semarang

Berdasarkan Gambar 1 menunjukkan bahwa pada kelompok kecepatan persentase tertinggi adalah kategori "sedang", yaitu sebesar 50\%. Kategori kecepatan yang paling rendah persentasenya adalah kategori "baik sekali. Hal ini perlu adanya latihan untuk meningkatkan kecepatan seorang atlet, karena dalam olahraga futsal komponen kecepatan sangat diperlukan pada saat pemain menggiring bola (Ni'mah, 2018). Bentuk latihan yang dapat meningkatkan kecepatan adalah latihan S-A-Q (Speed, Agility, Quickness). "SAQ merupakan bentuk latihan dari kecepatan, kelincahan, kecepatan dalam merespon stimulus dan non stimulus" (Apriliyanto, 2020). Bentuk latihan untuk meningkatkan kecepatan dalam SAQ adalah latihan speed ABC run (Soemardiawan \& Yundarwati, 2018). 
Sepakbola, 1 (1), 2021, 5

Adi Purnomo, Fajar Awang Irawan

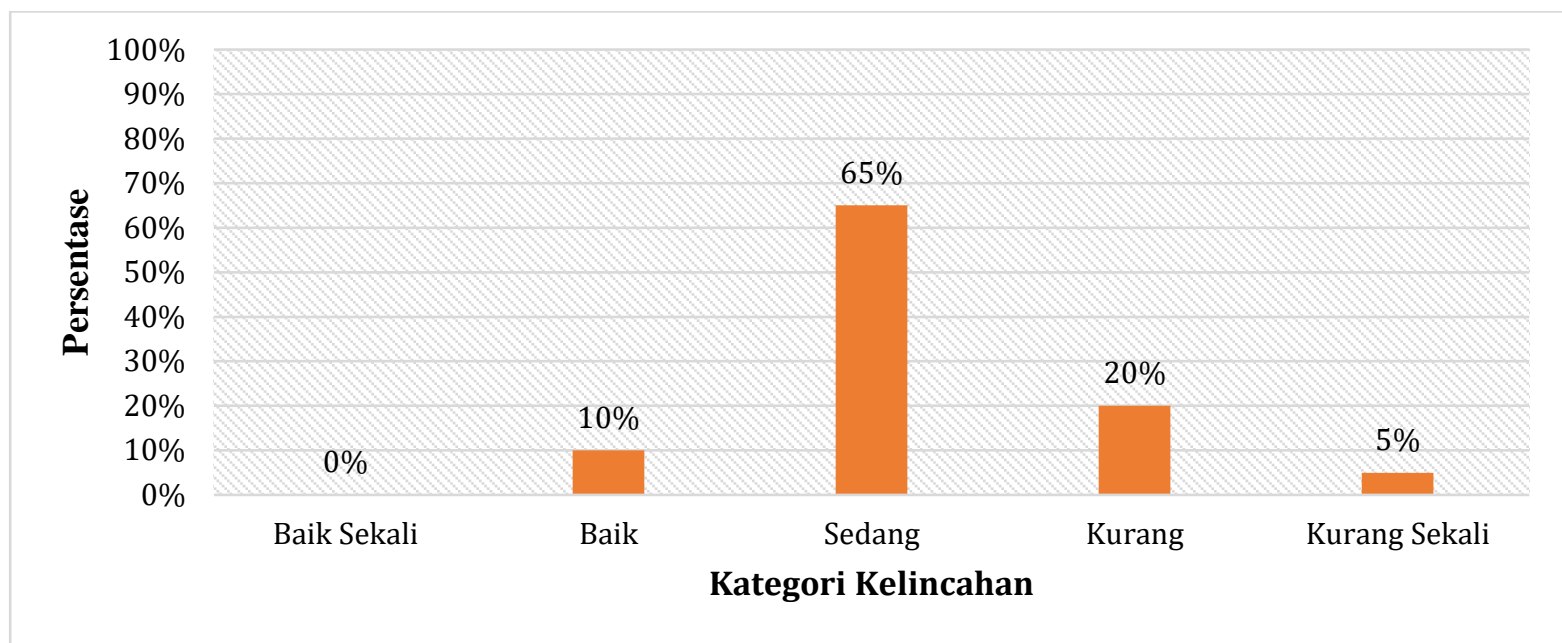

Gambar 2. Grafik kategori tingkat kelincahan atlet futsal Jatidiri Muda Semarang

Gambar 2 menunjukkan bahwa kategori kelincahan yang paling tinggi persentasenya adalah kategori "sedang". Maka, perlu dilakukannya latihan yang dapat meningkatkan kelincahan atlet. Bentuk latihan yang dapat meningkatkan kelincahan atlet adalah S-A-Q (Speed, Agility, Quickness). Selain dapat melatih kecepatan, bentuk latihan ini juga dapat melatih kelincahan seorang atlet. Selaras dengan pernyataan (Johnson \& Bujjibabu, 2012) menjelaskan bahwa SAQ dapat meningkatkan kemampuan kecepatan dan kemampuan kelincahan seorang atlet. Bentuk latihan kelincahan dalam SAQ adalah latihan lari zig-zag (Soemardiawan \& Yundarwati, 2018). Kelincahan sangat diperlukan dalam olahraga futsal, khususnya pada saat pemain menggiring bola (Ni'mah, 2018).

Menggiring bola merupakan salah satu teknik futsal yang harus dikuasai bagi setiap pemain (Ni'mah, 2018). Berdasarkan hasil penelitian tentang keterampilan menggiring bola, atlet futsal Jatidiri Muda tergolong "sedang". Hasil tersebut dapat dilihat seperti Gambar 3.

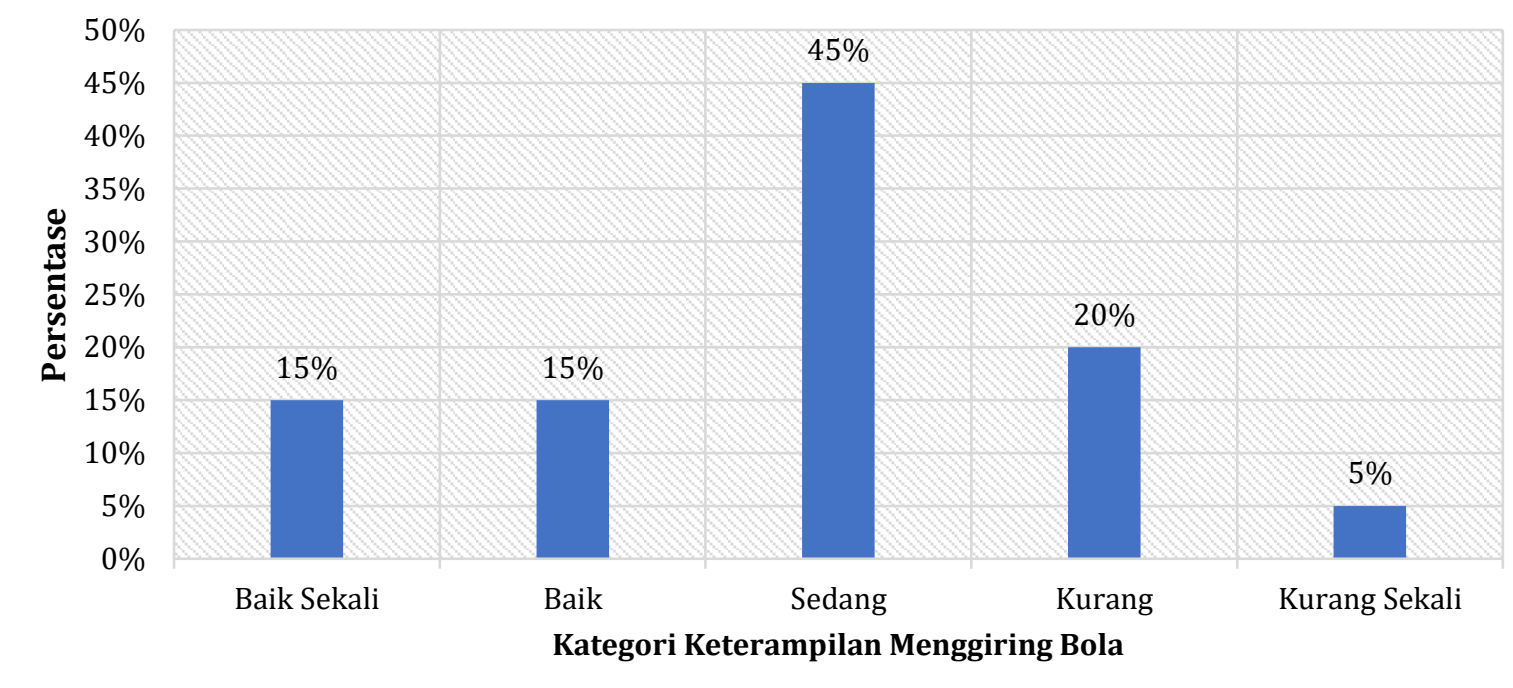

Gambar 3. Kategori tingkat keterampilan menggiring bola atlet futsal Jatidiri Muda Semarang

Gambar 3 menunjukkan bahwa kategori keterampilan menggiring bola atlet masih belum mencapai tingkat "sangat baik" dalam menggiring bola. Perlu adanya latihan yang dapat meningkatkan keterampilan menggiring bola, karena menggiring bola merupakan unsur penting bagi setiap pemain futsal. Salah satu faktor yang mempengaruhi hasil dalam keterampilan menggiring bola adalah kecepatan dan kelincahan (Šimonek et al., 2017).

Berdasarkan hasil penelitian menjelaskan bahwa adanya hubungan antara kecepatan dengan keterampilan menggiring bola pada tim futsal Jatidiri Muda Semarang. Hal ini sangat relefan dengan hasil penelitian (Gunawan \& Suherman, 2016) yang menyimpulkan bahwa "Terdapat 
Sepakbola, 1 (1), 2021, 6

Adi Purnomo, Fajar Awang Irawan

hubungan yang signifikan antara kecepatan terhadap kemampuan dribbling bola futsal dan memiliki hubungan positif yang sangat kuat". Pernyataan (Ni'mah, 2018) menjelaskan bahwa "Kecepatan memepengaruhi hasil menggiring bola sebanyak $22,2 \%$ dan sisanya berasal dari faktor lain". Berdasarkan penjelasan tersebut dapat disimpulkan bahwa kecepatan seseorang dapat memberi pengaruh pada hasil menggiring bola.

Hasil pada penelitian ini juga menjelaskan bahwa adanya hubungan antara kelincahan dengan keterampilan dalam menggirng bola pada tim futsal Jatidiri Muda Semarang. Hal ini sangat relefan dengan hasil penelitian yang dilakukan (Gunawan \& Suherman, 2016) yang menyimpulkan bahwa "Terdapat hubungan yang signifikan antara kelincahan terhadap kemampuan dribbling bola futsal dan memiliki hubungan positif yang sangat kuat". Memiliki kelincahan yang tinggi dapat meminimalisir keluarnya tenaga dalam suatu pertandingan dan menggiring bola (Ni'mah, 2018). Kelincahan merupakan salah satu faktor yang berhubungan dengan keterampilan menggiring bola seorang atlet karena dibutuhkan koordinasi antara keseimbangan dan kecepatan (Gunawan \& Suherman, 2016). Fakor yang mempengaruhi kelincahan saat menggiring bola adalah kemampuan mengubah gerakan. Berbeda dengan kecepatan, (Darmawan et al., 2020) menjelaskan bahwa bersarnya kontribusi kelincahan terhadap kemampuan menggiring bola adalah 31,6\%. Berdasarkan penjelasan tersebut dapat disimpulkan bahwa kelincahan seseorang dapat memberi pengaruh penting dalam menggiring bola.

Hal ini dapat diartikan bahwa adanya hubungan antara kecepatan dan kelincahan seseorang terhadap keterampilan dalam menggiring bola. Sesuai dengan hasil dalam penelitian ini yang menjelaskan bahwa adanya hubungan antara kecepatan dan kelincahan terhadap atlet futsal tim Jatiri Muda Semarang. Hasil tersebut sangat relefan dengan pernyataan (Gunawan \& Suherman, 2016) bahwa kecepatan dan kelincahan adalah salah satu kemampuan fisik yang berperan penting dalam penguasaan menggiring. Hal ini juga dijelaskan oleh (Ni'mah, 2018) bahwa kecepatan dan kelincahan merupakan keterampilan fisik yang dapat mengubah arah dengan cepat dan efisien pada saat menggiring bola.

\section{SIMPULAN}

Berdasarkan hasil dan pembahasan dalam penelitian ini dapat diperoleh kesimpulan sebagai berikut: (1) Adanya hubungan antara kecepatan terhadap keterampilan dalam menggiring bola pada tim futsal Jatidiri Muda Semarang. (2) Adanya hubungan antara kelincahan terhadap keterampilan dalam menggiring bola pada tim futsal Jatidiri Muda Semarang. (3) Kecepatan dan kelincahan memiliki hubungan yang signifikan terhadap keterampilan menggiring bola tim futsal Jatidiri Muda Semarang.

\section{UCAPAN TERIMA KASIH}

Penulis menyampaikan terimakasih kepada orang tua penulis yang telah memberikan motivasi dan doa agar menyelesaikan skripsi dengan baik dan cepat.

\section{DAFTAR PUSTAKA}

Akhmad, N., Zainuddin, F., \& Bausad, A. A. (2018). Hubungan antara kecepatan dan kelincahan terhadap keterampilan menggiring bola dalam sepak bola pada Klub Red Bee Warrior Mataram tahun 2018. JISIP (Jurnal Ilmu Sosial Dan Pendidikan), 2(1), 55-61. https://doi.org/10.36312/jisip.v2i1.603

Apriliyanto, R. (2020). Pengaruh pelatihan speed, agility, quickness (SAQ) terhadap kecepatan reaksi penjaga gawang sepakbola. COMPETITOR: Jurnal Pendidikan Kepelatihan Olahraga, 12(2), 120. https://doi.org/10.26858/cjpko.v12i2.13792

Darmawan, F. D., Sulaiman, S., \& Setyawati, H. (2020). Contributions agility, resilience and selfconfidence against ball dribbling skills (dribbling) futsal. Journal of Physical Education and Sports, 9(1), 14-19. https://journal.unnes.ac.id/sju/index.php/jpes/article/view/36348

Gunawan, Y. R., \& Suherman, A. (2016). Hubungan kecepatan dan kelincahan terhadap kemampuan dribbling bola futsal pada atlet O2Sn Kecamatan Sumedang Utara. SpoRTIVE 
Sepakbola, 1 (1), 2021, 7

Adi Purnomo, Fajar Awang Irawan

(Sport, Research, Treatment, Innovation of Learning and Value Education), 1(1), 1-12.

https://ejournal.upi.edu/index.php/SpoRTIVE/article/view/3413

Irawan, A. Y., \& Hariadi, I. (2019). Hubungan antara kecepatan dan kelincahan dengan keterampilan menggiring bola. Sport Science and Health, 1(3), 222-226.

http://journal2.um.ac.id/index.php/jfik/article/view/11359

Johnson, P., \& Bujjibabu, M. (2012). Effect of plyometric and speed agility and quickness (SAQ) on speed and agility of male football players. Asian Journal of Phisical Education and Computer Science in Sport, 7(1), 26-30.

Lhaksana, J. (2011). Taktik \& strategi futsal modern. Be Champion.

Ni'mah, A. K. (2018). Hubungan kecepatan, kelincahan, dan keterampilan menggiring bola pada pemain futsal [Universitas Muhammadiyah Surakarta]. http://eprints.ums.ac.id/62631/

Nurhasan, C. (2011). Tips praktis menjaga kebugaran jasmani. Abil Pustaka.

Saputra, M., \& Perdima, F. E. (2020). Hubungan kecepatan terhadap keterampilan dribbling pada permainan futsal di Akademi Dehasen Kota Bengkulu. Journal Of Dehasen Educational Review, 1(1), 38-43. https://doi.org/10.33258/jder.v1i1.978

Šimonek, J., Horička, P., \& Hianik, J. (2017). The differences in acceleration, maximal speed and agility between soccer, basketball, volleyball and handball players. Journal of Human Sport and Exercise, 12(1), 73-82. https://doi.org/10.14198/jhse.2017.121.06

Soemardiawan, S., \& Yundarwati, S. (2018). Pengembangan model latihan SAQ (speed, agility, quickness) terhadap peningkatan kecepatan dan kelincahan pada pemain futsal Fim Squad IKIP Mataram tahun 2018. Jurnal Ilmiah IKIP Mataram, 5(1), 32-40.

https://ojs.ikipmataram.ac.id/index.php/jiim/article/view/1121

Sunarno, S. (2008). Futsal: Sepak bola dalam ruangan. CV. Aneka Ilmu.

Tenang, J. D. (2007). Jurus pintar main bola. DARI Mizan.

Widiastuti, W. (2019). Tes dan pengukuran olahraga. Rajawali Pers. 